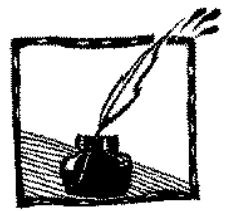

\title{
Dlaczego konieczne jest odbudowanie dawniej istniejącej jedności matematyki i fizyki teoretycznej"
}

Andrzej Staruszkiewicz Instytut Fizyki UJ

Gdy organizatorzy dzisiejszej uroczystości zwrócili się do mnie z propozycją wygłoszenia referatu, to pierwszą myślą, która przyszła mi do głowy była ta, że większą część mojego naukowego życia przeżyłem jako członek tej samej Rady Wydziału co Rektor Pelczar. Potem matematycy i fizycy UJ utworzyli odrębne Rady Wydziału, co było wydarzeniem smutnym, chociaż pewnie nieuniknionym, to zaś doprowadziło mnie do tematu dzisiejszych rozważań.

Jeszcze stosunkowo niedawno ci sami ludzie potrafili dokonywać wybitnych odkryć zarówno w matematyce, jak i w fizyce teoretycznej. Ustaliła się tradycja, żeby Newtona uważać za fizyka, wszyscy jednak pamiętamy, że był on też jednym $\mathrm{z}$ największych matematyków $\mathrm{w}$ historii. Euler, przeciwnie, jest uważany przez tradycję za matematyka. Mało kto zdaje sobie sprawę z tego, że Euler był też jednym z największych fizyków. W szczególności, równania różniczkowe zwyczajne $m a=F$, gdzie $m$ jest masą, $a$ przyspieszeniem, a $F$ siłą, które my nazywamy równaniami Newtona, zostały po raz pierwszy napisane przez Eulera. Doniosłość tego odkrycia Eulera polega na tym, że prawda naukowa, którą Newton odkrył i opisał w Principiach została ostatecznie zapisana w postaci układu równań różniczkowych zwyczajnych. Tym samym problemy mechaniczne, które Newton rozwiązuje w Principiach za pomocą rozumowań geometrycznych, genialnych, ale niedostępnych dla zwykłego śmiertelnika, zostały sprowadzone do problemów czysto analitycznych.

Dzieło Eulera, które można określić jako sprowadzenie mechaniki do analizy, kontynuował Lagrange, też uważany

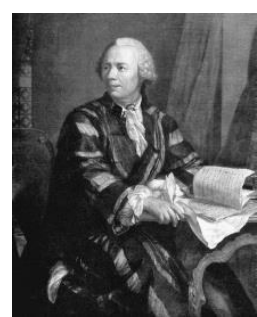

Leonhard Euler $(1707-1783)$

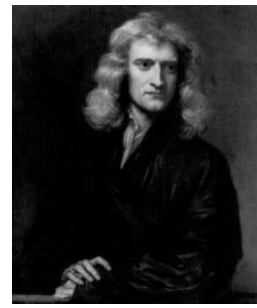

Isaac Newton $(1643-1727)$

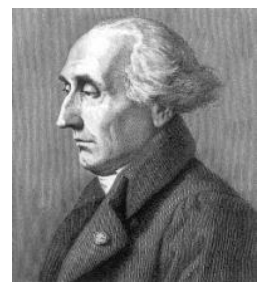

Joseph Louis Lagrange $(1736-1813)$ przez tradycję za matematyka. Méchanique analitique Lagrange'a, opublikowana równo 100 lat po Principiach Newtona, jest miarą osiągniętego postępu. O ile Principia są prawie niedostępne dla współczesnego

* Wykład wygłoszony 21 kwietnia 2007 r. z okazji 70. rocznicy urodzin prof. Andrzeja Pelczara. Roczniki Polskiego Towarzystwa Matematycznego, Seria II: Wiadomości Matematyczne XLIV (2008), za zgodą autora i redakcji WM. 


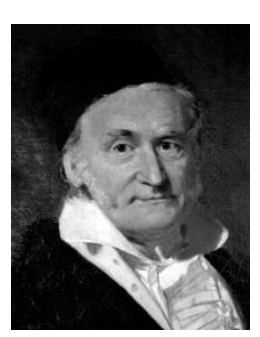

Carl Friedrich Gauss (1777-1855)

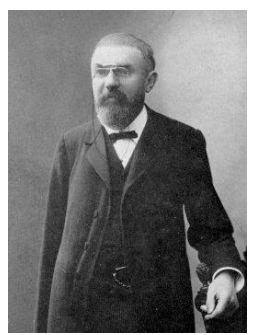

Henri Poincaré (1854-1912)

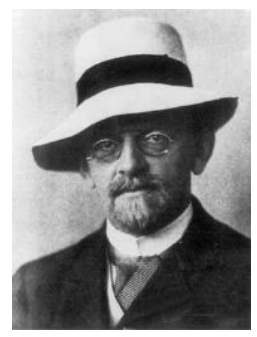

David Hilbert (1862-1943)

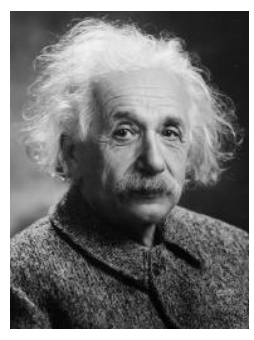

Albert Einstein (1879-1955) czytelnika ${ }^{1}$, o tyle Méchanique analitique tylko nieznacznie różni się od tego, co obecnie wykłada się studentom fizyki jako mechanikę.

W XIX wieku mamy wspaniałą postać Gaussa. Znowu mało kto pamięta, że ten wielki matematyk był przez kilkadziesiąt lat dyrektorem Obserwatorium Astronomicznego w Getyndze, a jego prace $z$ kartografii, astronomii, elektryczności i magnetyzmu czynią go jednym $\mathrm{z}$ największych przyrodników XIX wieku. W fizyce po dziś dzień jedno $\mathrm{z}$ równań Maxwella nazywa się równaniem Gaussa. Na cześć Gaussa nazwano gausem jednostkę gęstości strumienia magnetycznego. Od Gaussa pochodzi też najracjonalniejszy układ jednostek w elektrodynamice, powszechnie używany w podręcznikach fizyki teoretycznej. Wprowadzony następnie przez „praktyków" system SI, prawnie obowiązujący we wszystkich krajach, jest naukowym absurdem, którym niepotrzebnie dręczy się uczniów szkół średnich i studentów fizyki niższych lat.

Jeszcze na początku XX wieku Poincaré i Hilbert dokonali odkryć, które stanowią trwały wkład w rozwój fizyki teoretycznej. Poincaré odkrył jeszcze przed Einsteinem znaczną część tego zespołu idei, który nosi nazwę Szczególnej Teorii Względności. Mimo to werdykt historii, który zasługę dokonania tego epokowego odkrycia przypisuje Einsteinowi, jest sprawiedliwy. Relacja między Poincarém a Einsteinem jest taka, jak między Wikingami a Kolumbem. Wiadomo obecnie, że Wikingowie byli w Ameryce przed Kolumbem, ale nie zdawali sobie z tego sprawy. Podobnie Poincaré, przypuszczalnie pod wpływem wyznawanej przez siebie filozofii konwencjonalizmu, nie docenił znaczenia własnych odkryć. Obecnie o wkładzie Poincarégo przypomina nam grupa Poincarégo, która jest grupą ruchów czasoprzestrzeni w Szczególnej Teorii Względności.

Wkład Hilberta do rozwoju Ogólnej Teorii Względności był jeszcze donioślejszy. O ile Szczególna Teoria Względności jest czasoprzestrzennym odpowiednikiem Geometrii Euklidesa i jako struktura matematyczna jest strukturą bardzo prostą, o tyle Ogólna Teoria Względności nie jest strukturą prostą. Podstawową trudnością, z którą Einstein zmagał się przez kilka lat było ustalenie prawidłowej postaci równań ruchu dla pola grawitacyjnego. Hilbert wpadł na znakomitą

${ }^{1}$ Ukazały się polskie thumaczenia Principiów, zob. Foton 131. 
myśl, że zamiast szukać równań ruchu, należy szukać działania Hamiltona, dla którego równania ruchu są równaniami Lagrange'a-Eulera. Takie postawienie sprawy pozwala od razu dojść do prawidłowej postaci równań ruchu, które Hilbert istotnie otrzymał na 4 dni przed Einsteinem. Jako szczególnie budującą warto podkreślić tę okoliczność, że Hilbert nigdy nie usiłował stwarzać wrażenia, że miał cokolwiek wspólnego z odkryciem Ogólnej Teorii Względności, przeciwnie zawsze podkreślał, że jest to od początku do końca dzieło Einsteina. Jego zasługi zostały jednak docenione przez ludzi zainteresowanych przedmiotem, co wyraża się m.in. tym, że działanie Hamiltona dla pola grawitacyjnego nazywa się powszechnie działaniem Hilberta.

Przykłady powyższe przytoczyłem, żeby zilustrować, co następuje. Matematyka polega na rozwiązywaniu problemów matematycznych, a fizyka teoretyczna jest szczególnie obfitym źródłem takich problemów. Nie ma więc nic dziwnego w tym, że matematycy uczestniczą w rozwiązywaniu tych problemów. Tak było i tak pewnie będzie zawsze. Jednakże aż do początku XX wieku rola matematyków, chociażby tych wyżej wymienionych: Eulera, Lagrange'a, Gaussa, Poincarégo i Hilberta, była znacznie istotniejsza. Oni nie tylko rozwiązywali problemy matematyczne, ale uczestniczyli w tworzeniu tego, co stanowi fizykę teoretyczną.

Ta szczęśliwa sytuacja współtworzenia fizyki teoretycznej przez matematyków, jak gdyby skończyła się wraz z odkryciem w latach dwudziestych XX wieku mechaniki kwantowej i kwantowej teorii pola, będącej relatywistycznym rozwinięciem mechaniki kwantowej. Zdaję sobie sprawę z tego, że niektórzy ludzie mogą nie zgodzić się z tą opinią, wskazując np. na dzieło von Neumanna Mathematische Grundlagen der Quantenmechanik. Inni mogą wskazać na działalność laureata medalu Fieldsa, Edwarda Wittena. Wątpliwości tego rodzaju skomentuję dalej. Na razie po prostu powiem, że sformułowaną wyżej opinię uważam za prawdziwą i zastanowię się nad możliwymi przyczynami tego stanu rzeczy.

Mechanika kwantowa stanowi odkrycie tej samej rangi co odkrycia Newtona. Mechanika kwantowa opisuje zachowanie się cząstek elementarnych, takich jak elektron.

Otóż świat cząstek elementarnych powinien zainteresować matematyków dlatego, że stanowi niejako matematykę ucieleśnioną. Swego czasu Platon tak opisał różnice między przedmiotami matematycznymi a przedmiotami fizycznymi:

Należy wyróżnić następujące problemy: czym jest to co zawsze trwa i nie zna urodzin; czym jest to, co się zawsze rodzi i nigdy nie istnieje. Pierwszą rzecz może pojąć tylko intelekt za pomocą rozumowania, bo istnieje zawsze jako ta sama. Przeciwnie, druga jest przedmiotem mniemania w połączeniu $\mathrm{z}$ nie rozumowym poznaniem zmysłowym, bo rodzi się i umiera. 
Według Platona przedmioty matematyczne są niezniszczalne i zawsze takie same. Przedmioty fizyczne, przeciwnie, mają swoją indywidualną historię $\mathrm{i}$ indywidualne odstępstwa od normy, np. gatunkowej. To przeciwstawienie uważano za trafne przez ponad 2000 lat. Każdy nauczyciel przypominał uczniom, że nawet najbardziej starannie narysowany okrąg nigdy nie będzie okręgiem matematycznym. Otóż w świecie cząstek elementarnych rozróżnienie Platona po prostu przestaje obowiązywać! Wszystkie elektrony we Wszech-

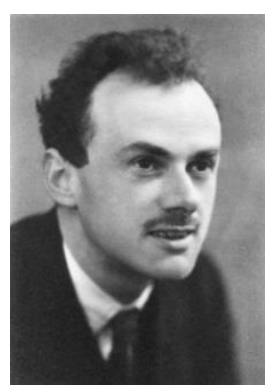

Paul A.M. Dirac (1902-1984) świecie są dokładnie takie same, a twierdzenie to ma taki sam stopień ścisłości jak twierdzenia matematyki. Wiemy też, $\mathrm{z}$ badania światła odległych galaktyk, że elektrony nie starzeją się, miliard lat temu były takie same jak obecnie. Twórcy mechaniki kwantowej, zwłaszcza Dirac, bardzo szybko zdali sobie sprawę z niezwykłości świata cząstek elementarnych. Dirac zaproponował, by do badania tego świata zastosować Zasadę Identyfikacji. Aby zrozumieć, co to jest Zasada Identyfikacji Diraca, wyobraźmy sobie, że wszystkie możliwe struktury matematyczne są spisane w pewnej Księdze, tak jak słowa polskie są spisane w słowniku języka polskiego. Otóż według Diraca, fizyk teoretyk powinien przeglądać Księgę, zastanawiając się cały czas, czy to co widzi nie przypomina mu czegoś co widział przedtem w rzeczywistości fizycznej. Dobra fizyka teoretyczna powstanie wówczas, gdy to, co znajdziemy w Księdze, w oczywisty i nie budzący wątpliwości sposób będzie przypominać to, co widzieliśmy wcześniej w rzeczywistości fizycznej.

Jest zupełnie oczywiste, że ten program badawczy Diraca nie ma żadnego sensu w odniesieniu do przedmiotów i zjawisk makroskopowych. Nie ma sensu pisać alternatywnych historii Polski w nadziei, że z czasem trafi się na prawdziwą. Nie ma sensu opisywać alternatywnych zwierząt w nadziei, że z czasem trafi się na słonia. Tymczasem w odniesieniu do świata cząstek elementarnych program Diraca ma oczywisty sens, właśnie z powodu podobieństwa tego świata do świata idei matematycznych, co niestety nie oznacza, że jest on łatwy do zrealizowania. Tu od razu mogę wspomnieć Edwarda Wittena. Jego teoria strun jest naiwnie dosłowną realizacją programu Diraca: powodowani przesłankami natury matematyczno-estetycznej, teoretycy strun badają różne struktury matematyczne, w których chcieliby doszukać się czegoś fizycznie użytecznego. Jeżeli uznać, że to się nie udało, a taki pogląd utrwala się coraz bardziej, to stanowi to bardzo poważne ostrzeżenie: nawet talent laureata medalu Fieldsa, wspomaganego przez kilkuset niemal równie utalentowanych zwolenników, nie wystarczy, żeby posłużyć się skutecznie Zasadą Identyfikacji Diraca.

$\mathrm{Na}$ czym więc powinna polegać rola matematyków we współtworzeniu współczesnej fizyki teoretycznej? Sądzę, że godnym naśladowania ideałem jest rola, jaką Euler i Lagrange odegrali w stosunku do Newtona. Uważając za 
oczywiste, że Newton odkrył ważne prawdy o rzeczywistości fizycznej, Euler i Lagrange nadali tym prawdom prostą i przejrzystą formę matematyczną.

Otóż nie ma cienia wątpliwości, że współczesna kwantowa teoria pola, będąca relatywistyczną wersją mechaniki kwantowej, zawiera ważne prawdy naukowe, że w naukowo poprawny sposób rozpoznaje wiele istotnych cech świata cząstek elementarnych. Jednocześnie jako struktura matematyczna praktycznie nie istnieje, nie można bowiem uważać za strukturę matematyczną schematu myślowego, w którym najprostsze rachunki prowadzą do rozbieżnych całek. Całkom tym nadaje się skończone wartości za pomocą specjalnych, ad hoc skomponowanych regul, które z matematyką nie mają nic wspólnego, stanowią raczej rodzaj ludowej mądrości ludzi, którzy muszą sobie jakoś radzić w różnych trudnych sytuacjach życiowych. Matematycy, którzy w stosunku do kwantowej teorii pola odegraliby rolę Eulera i Lagrange'a, bardzo przysłużyliby się ludzkości.

Tutaj muszę powiedzieć, że należy koniecznie odróżniać matematyczną ścisłość od matematycznej pedanterii. W kwantowej teorii pola brakuje matematycznej ścisłości w tym sensie, że podstawowy obiekt badania, a mianowicie pole kwantowe, jest dystrybucją, dla której nie są zdefiniowane operacje nieliniowe, tymczasem sens fizyczny tej teorii domaga się przeprowadzania operacji nieliniowych, np. przy konstruowaniu tensora energii i pędu pola kwantowego. Od takiej sytuacji rzeczywistego braku matematycznej jasności trzeba odróżniać swobodę, której dopuścił się Dirac w swojej wersji mechaniki kwantowej, w której to swobodzie tak naprawdę nie ma żadnej nieścisłości. Tu warto wspomnieć von Neumanna i jego książkę. Wiadomo, że motywacją dla von Neumanna było sformułowanie mechaniki kwantowej w sposób matematycznie poprawny, bez użycia rzeczy nieistniejących takich jak delta Diraca. Sformułowanie i notację samego Diraca, podane w jego

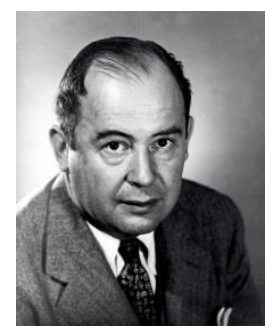

John von Neumann (1903-1957) książce The Principles of Quantum Mechanics można określić jako naiwne rozszerzenie na przestrzeń Hilberta tej algebry liniowej, która obowiązuje w skończenie wymiarowej przestrzeni wektorowej nad ciałem liczb zespolonych, wyposażonej w półtoraliniowy, hermitowski i dodatnio określony iloczyn skalarny. Wiadomo dobrze, że aż tak naiwnie nie można postępować, gdyż pewne twierdzenia prawdziwe $\mathrm{w}$ skończenie wymiarowej przestrzeni wektorowej przestają być prawdziwe w przestrzeni Hilberta. Na przykład twierdzenie, że spektrum operatora symetrycznego jest zawsze rzeczywiste, które jest prawdziwe w skończenie wymiarowej przestrzeni wektorowej przestaje być prawdziwe w przestrzeni Hilberta. Formalnie zatem motywacja von Neumanna była uzasadniona. $Z$ drugiej jednak strony muszę powiedzieć, jako praktykujący ponad 50 lat fizyk teoretyk, że nie znam przypadku, w którym notacja Diraca wprowadziłaby kogoś w błąd. Jest tak dlatego, że złośliwe operatory syme- 
tryczne, których spektrum wypełnia np. całą płaszczyznę zespoloną, można wprawdzie skonstruować, ale w naturalny sposób nie pojawiają się one w praktyce fizyka czy chemika kwantowego. Jeżeli więc za cel von Neumanna uważać stworzenie alternatywy dla terminologii i notacji Diraca, to można na pewno powiedzieć, że cel ten nie został osiągnięty: wszyscy fizycy na świecie stosują mechanikę kwantową w wersji Diraca i nic złego z tego powodu się nie dzieje.

Podsumowując: ani von Neumann, ani Witten, ani żaden inny matematyk nie dokonali niczego, co można by porównać z dziełem Eulera i Lagrange’a. Dlaczego? Tak naprawdę to nie wiem. Podejrzewam jednak, że fakt ten może być związany z brakiem filozoficznej jasności, który od początku towarzyszy mechanice kwantowej. Fizyka Newtona zakłada prostą i zrozumiałą dla każdego ontologię: istnieją tylko atomy materii i próżnia będąca czasoprzestrzenią Galileusza i Newtona. Tymczasem w mechanice kwantowej jej ontologia pozostaje po dziś dzień niejasna. Wyobrażam sobie, że może to odstręczać ludzi lubiących klarowność idei. Irlandzki fizyk J.L. Synge napisał, że od studiowania mechaniki kwantowej odstręczył go właśnie brak filozoficznej jasności. Być może tak samo jest w przypadku matematyków, którzy wolą zajmować się swoją tradycyjną tematyką niż próbować zrozumieć coś, czego sami fizycy ewidentnie nie rozumieją. 